\title{
Studies on influence of modified atmospheric storage conditions on biochemical parameters in pigeonpea seeds
}

\author{
B. Manjunatha ${ }^{1 *}$, S. N. Vasudevan ${ }^{1}$, Umesha $^{1}$ and Chintalapati Sravani $^{2}$ \\ ${ }^{1}$ Department of Seed Science and Technology, College of Agriculture, University of Agricultural Sciences, Raichur \\ -584102 (Karnataka), INDIA. \\ ${ }^{2}$ Department of Seed Science and Technology, College of Agriculture, University of Agricultural Sciences, GKVK, \\ Bangalore-560065 (Karnataka), INDIA \\ *Corresponding author. E-mail: manjuraj522@gmail.com
}

Received: December 24, 2014; Revised received: April 02, 2016; Accepted: July 15, 2016

\begin{abstract}
An experiment was conducted to study the influence of modified atmospheric storage conditions on biochemical parameters of pigeonpea seeds. The experiment was conducted at the Department of Seed Science and Technology, College of Agriculture, Raichur, Karnataka. The seeds are exposed to various gaseous combinations and stored in 700 gauge polyethylene bag for ten months during July-2012 to April- 2013. The results revealed that, the seeds exposed to gaseous combination of $40 \% \mathrm{~N}_{2}+00 \% \mathrm{O}_{2}+60 \% \mathrm{CO}_{2}$ showed less reduction in dehydrogenase enzyme activity and protein content (0.276 OD (optical density) value, $19.33 \%$ respectively) as compared to the control (0.211 OD value and $18.13 \%$ respectively) after ten months of storage. In addition less seed leachate (2.029 $\mathrm{dSm}^{-1}$ ) was recorded in gaseous combination of $40 \% \mathrm{~N}_{2}+00 \% \mathrm{O}_{2}+60 \% \mathrm{CO}_{2}$ as compared to control $\left(2.207 \mathrm{dSm}^{-1}\right)$. It indicates the potential use of modified atmospheric storage technology for maintenance of seed viability and vigour during storage in pulses.
\end{abstract}

Keywords: Carbon dioxide, MAP, Nitrogen, Oxygen, Pigeonpea

\section{INTRODUCTION}

Pigeonpea [Cajanus cajan (L.)] is an important pulse crop in India. It is also known as red gram, arhar and tur. In India, it is one of the very important grain legumes and occupies second position in area and production next to chickpea. It is mainly grown in the states of Maharashtra, Karnataka, Uttar Pradesh, Madhya Pradesh and Gujarat. It is grown on an area of $4.04 \mathrm{~m}$ ha with an annual production of 2.65 million tonnes and a productivity of $656 \mathrm{~kg}$ per ha. Its area, production and productivity trends in India in last five decades showed that there was about 2 per cent increase in area per year but the yield levels were stagnated around 600-700 kg per ha. In Karnataka, pigeonpea occupies second place in area $(0.77 \mathrm{mha})$ and ranks second in production $(0.36 \mathrm{mt})$ with a productivity of $466 \mathrm{~kg}$ per ha (Anonymous, 2012).

Proper storage of seed in seed production programme is an important activity in order to maintain its quality parameters like viability, vigour and seed health until it is sown. Now a days seed consumer, tiller of the land demand for high quality seeds. Supplying high quality seeds can be achieved by an appropriate postharvest storage technology (Shivappa, 2011). A major cause of stored seed degradation and deterioration are insect pests and microorganisms. Many studies have shown that modified atmosphere of elevated carbon dioxide and depleted oxygen is effective method against insect and microorganisms during storage. Modified atmospheric storage is one of the seeds and food preservation methods that maintain the natural quality of food products in addition to extending the storage life. Modified atmosphere (MA) reduces the respiration rate of seeds and activity of insects or microorganisms in seeds (Jayas and Jeyamkondan, 2002).

The only technology that retains the special capacity of fumigation for in-situ treatment of stored commodities, as well as offering a similar diversity of application technologies, is the modified atmosphere (MA) method. Modified atmosphere offer an alternative that is safe and environmentally benign to the use of conventional residue-producing chemical fumigants for controlling insect pests attacking stored grains, oilseeds, pulses, processed commodities and packaged foods. Although the economics involved in the application of MA prevent their full replacement of conventional fumigants, novel approaches to the use of MA indicate their suitability for niche applications (Shlomo et al., 2004).

Disinfestations of stored seeds using modified atmospheric storage (MA) involves the alteration of the natural storage gases such as carbon dioxide $\left(\mathrm{CO}_{2}\right)$, oxygen $\left(\mathrm{O}_{2}\right)$ and nitrogen $\left(\mathrm{N}_{2}\right)$, to render the atmosphere in the stores lethal to pests. Modified atmosphere storage of seeds is a suitable alternative to the use of chemical fumigants and contact insecticides that are known to ISSN : 0974-9411 (Print), 2231-5209 (Online) All Rights Reserved @ Applied and Natural Science Foundation www.jans.ansfoundation.org 
leave carcinogenic residues in the treated product (Bailey and Banks, 1980).The loss in viability is accompanied by certain biochemical changes in seed. Therefore, the present investigation was carried out to Study the influence of modified atmospheric storage conditions on biochemical parameters in pigeonpea seeds.

\section{MATERIALS AND METHODS}

The experiments were conducted in the laboratory of Department of Seed Science and Technology, College of Agriculture, University of Agricultural Sciences, Raichur, Karnataka for ten months during July-2012 to April- 2013. Polyethylene bags of 700 gauge measuring $40 \mathrm{~cm}$ length and $25 \mathrm{~cm}$ breadth were used for packing purpose. In these bags, one $\mathrm{kg}$ of pigeonpea seeds (variety BSMR-736) was packed along with the gases like carbon dioxide, nitrogen and oxygen in different concentrations according to the treatments viz., ( $\mathrm{T}_{1}$-Control, $\mathrm{T}_{2}-\left(70 \% \mathrm{~N}_{2}+20 \% \quad \mathrm{O}_{2}+10 \% \mathrm{CO}_{2}\right), \mathrm{T}_{3}-(60$ $\left.\% \mathrm{~N}_{2}+20 \% \mathrm{O}_{2}+20 \% \mathrm{CO}_{2}\right), \mathrm{T}_{4}-\left(40 \% \mathrm{~N}_{2}+20 \% \mathrm{O}_{2}+40 \%\right.$ $\left.\mathrm{CO}_{2}\right), \mathrm{T}_{5}-\left(20 \% \quad \mathrm{~N}_{2}+20 \% \mathrm{O}_{2}+60 \% \quad \mathrm{CO}_{2}\right), \mathrm{T}_{6}-\left(80 \% \quad \mathrm{~N}_{2}\right.$

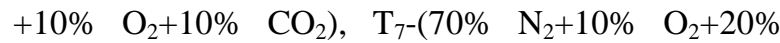
$\left.\mathrm{CO}_{2}\right), \mathrm{T}_{8}-\left(50 \% \quad \mathrm{~N}_{2}+10 \% \quad \mathrm{O}_{2}+40 \% \quad \mathrm{CO}_{2}\right), \mathrm{T}_{9}-(30 \%$

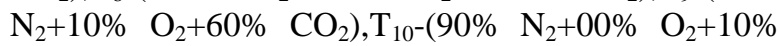
$\left.\mathrm{CO}_{2}\right), \mathrm{T}_{11}-\left(80 \% \quad \mathrm{~N}_{2}+00 \% \quad \mathrm{O}_{2}+20 \% \quad \mathrm{CO}_{2}\right), \mathrm{T}_{12}-(60 \%$ $\begin{array}{lllll}\mathrm{N}_{2}+00 \% & \mathrm{O}_{2}+40 \% & \left.\mathrm{CO}_{2}\right), \mathrm{T}_{13}-(40 \% & \mathrm{N}_{2}+00 \% & \mathrm{O}_{2}+60 \%\end{array}$ $\left.\mathrm{CO}_{2}\right), \mathrm{T}_{14}$-Vacuum). Firstly, the valves of the gas cylinders were opened and were released at a pressure of $7 \mathrm{~kg} / \mathrm{cm}^{2}$ and the different combinations of carbon dioxide, nitrogen and oxygen were mixed in the mixing chamber. According to the treatments given, gas flow rate was controlled in the buffer tank which was directly connected to the packaging unit. The pigeonpea seeds of $1 \mathrm{~kg}$ were packed using the packaging machine by evacuing the air, then flushing with the gases of required combinations followed by sealing automatically. Composition of the gas i.e., $\mathrm{O}_{2}$ and $\mathrm{CO}_{2}$ gas concentrations inside the package was checked by Check mate head space gas analyzer with the help of septum which prevents leakage of gas from polyethylene bag. The experiment was carried out in completely randomized design in three replications and observations on various seed quality parameters were recorded (2, 4, 6, 8 and 10) bimonthly.

Representative seeds (25) from each treatment were taken and preconditioned by soaking in water overnight at room temperature. Seeds were taken at random and the embryos were excised. The embryos were steeped in 0.25 per cent solution of 2,3,5-triphenyl tetrazolium chloride solution and kept in dark for two hours at $40^{\circ} \mathrm{C}$ for staining. The stained seeds were thoroughly washed with water and then soaked in 10 $\mathrm{ml}$ of 2 methoxy ethanol (methyl cellosolve) and kept overnight for extracting the red colour formazan. The intensity of red colour was measured using ELICO UV -VIS spectrophotometer (model SC-159) using blue filter $(470 \mathrm{~nm})$ and methyl cellosolve as the blank. The
OD value obtained was reported as dehydrogenase activity (Kittock and Law, 1968).

Five grams of seeds in four replicates were soaked with acetone for half a minute and thoroughly washed in distilled water for five times. Then the seeds soaked in $25 \mathrm{ml}$ distilled water and kept in an incubator maintained at $25 \pm 1{ }^{\circ} \mathrm{C}$ for 24 hours. The seed leachate was collected and volume was made up to $25 \mathrm{ml}$ by adding distilled water. The electrical conductivity of the seed leachate was measured in the digital conductivity bridge (ELICO) with a cell constant of 1.0 and the mean value expressed in deci Simons per meter.

Seed samples from each treatment were ground into fine powder. The seed samples were analyzed for protein content by Lowry's method (Lowry, et al., 1951) and protein content was finally expressed in $\mathrm{mg}$ per $100 \mathrm{~g}$ seed sample by referring to standard graph.

\section{RESULTS AND DISCUSSION}

Tetrazolium is a rapid test to estimate seed viabil-ity and vigor based on color alterations of seed living tissues in contact with a solution of 2,3,5 triphenyl tetrazolium chloride, thus reflecting the degree of activity of the dehydrogenase enzyme system closely related to seed respiration and viability (Julio, 2015).The dehydrogenase enzyme activity is a good stable metabolic marker to estimate the degree of vigour in seeds (Saxena et al., 1987) and have positive association with vigour and viability of seeds (Rudrapal and Basu, 1970; Halder and Gupta, 1982 and Kharlukhi, 1983).

Dehydrogenase activity declined with the advancement of storage period. The mean dehydrogenase activity decreased from 0.802 OD value at the initial stage to 0.240 OD value after ten months of storage. The $5 \%$ significant difference due to modified atmospheric storage conditions on dehydrogenase activity was recorded throughout the storage period. At the end of ten months of storage period, highest dehydrogenase activity was recorded in $\mathrm{T}_{13}\left(40 \% \mathrm{~N}_{2}+0 \% \mathrm{O}_{2}+60 \% \mathrm{CO}_{2}\right)$ 0.276 followed by $\mathrm{T}_{12}-\left(60 \% \mathrm{~N}_{2}+0 \% \quad \mathrm{O}_{2}+40 \% \quad \mathrm{CO}_{2}\right)$ 0.271 , while the lowest dehydrogenase activity was recorded in $\mathrm{T}_{1}$ (control) 0.211 (Table1).This gradual decline in dehydrogenase activity may be due to reduction in vigour level of seed as the deterioration occurs rapidly over a period of time under uncontrolled condition. The similar results of dehydrogenase activity were also reported by Shivappa (2011) in onion and Shrishail (2011) in groundnut.

The damage caused to membrane through deterioration that provides lower selectivity and hence increase in the leakage of solutes to the environment has been one of the main causes of the decline in the physiological quality of seeds. As result, the electrical conductivity test is considered as an important tool to evaluate the seed vigour, since it indirectly assesses the cell membrane degradation degree by determining the amount of electrolytes released in the seed soaking solution 
Table 1. Influence of modified atmospheric storage conditions on total dehydrogenase activity (OD value) of pigeonpea seeds during storage

\begin{tabular}{clccccc}
\hline & \multicolumn{2}{c}{ Treatments } & \multicolumn{5}{c}{ Months of storage (July-2012 to April 2013) } \\
\cline { 3 - 7 } & & $\mathbf{2}$ & $\mathbf{4}$ & $\mathbf{6}$ & $\mathbf{8}$ & $\mathbf{1 0}$ \\
\hline $\mathrm{T}_{1}$ & $:$ Control & 0.691 & 0.572 & 0.455 & 0.357 & 0.211 \\
$\mathrm{~T}_{2}$ & $: 70 \% \mathrm{~N}_{2}+20 \% \mathrm{O}_{2}+10 \% \mathrm{CO}_{2}$ & 0.700 & 0.603 & 0.485 & 0.367 & 0.220 \\
$\mathrm{~T}_{3}$ & $: 60 \% \mathrm{~N}_{2}+20 \% \mathrm{O}_{2}+20 \% \mathrm{CO}_{2}$ & 0.706 & 0.616 & 0.490 & 0.371 & 0.223 \\
$\mathrm{~T}_{4}$ & $: 40 \% \mathrm{~N}_{2}+20 \% \mathrm{O}_{2}+40 \% \mathrm{CO}_{2}$ & 0.719 & 0.627 & 0.492 & 0.379 & 0.226 \\
$\mathrm{~T}_{5}$ & $: 20 \% \mathrm{~N}_{2}+20 \% \mathrm{O}_{2}+60 \% \mathrm{CO}_{2}$ & 0.755 & 0.630 & 0.494 & 0.386 & 0.229 \\
$\mathrm{~T}_{6}$ & $: 80 \% \mathrm{~N}_{2}+10 \% \mathrm{O}_{2}+10 \% \mathrm{CO}_{2}$ & 0.761 & 0.639 & 0.498 & 0.387 & 0.232 \\
$\mathrm{~T}_{7}$ & $: 70 \% \mathrm{~N}_{2}+10 \% \mathrm{O}_{2}+20 \% \mathrm{CO}_{2}$ & 0.768 & 0.645 & 0.504 & 0.394 & 0.234 \\
$\mathrm{~T}_{8}$ & $: 50 \% \mathrm{~N}_{2}+10 \% \mathrm{O}_{2}+40 \% \mathrm{CO}_{2}$ & 0.764 & 0.657 & 0.516 & 0.398 & 0.237 \\
$\mathrm{~T}_{9}$ & $: 30 \% \mathrm{~N}_{2}+10 \% \mathrm{O}_{2}+60 \% \mathrm{CO}_{2}$ & 0.765 & 0.660 & 0.524 & 0.401 & 0.240 \\
$\mathrm{~T}_{10}$ & $: 90 \% \mathrm{~N}_{2}+00 \% \mathrm{O}_{2}+10 \% \mathrm{CO}_{2}$ & 0.766 & 0.662 & 0.549 & 0.405 & 0.245 \\
$\mathrm{~T}_{11}$ & $: 80 \% \mathrm{~N}_{2}+00 \% \mathrm{O}_{2}+20 \% \mathrm{CO}_{2}$ & 0.768 & 0.664 & 0.551 & 0.408 & 0.250 \\
$\mathrm{~T}_{12}$ & $: 60 \% \mathrm{~N}_{2}+00 \% \mathrm{O}_{2}+40 \% \mathrm{CO}_{2}$ & 0.772 & 0.671 & 0.556 & 0.429 & 0.271 \\
$\mathrm{~T}_{13}$ & $: 40 \% \mathrm{~N}_{2}+00 \% \mathrm{O}_{2}+60 \% \mathrm{CO}_{2}$ & 0.777 & 0.677 & 0.561 & 0.432 & 0.276 \\
$\mathrm{~T}_{14}$ & $: \mathrm{Vacuum}$ & 0.770 & 0.669 & 0.553 & 0.425 & 0.269 \\
& Mean & 0.748 & 0.642 & 0.516 & 0.395 & 0.240 \\
& $\mathrm{~S}$. Em \pm & 0.010 & 0.014 & 0.007 & 0.006 & 0.006 \\
& $\mathrm{CD}(5 \%)$ & 0.031 & 0.043 & 0.022 & 0.019 & 0.019 \\
\hline
\end{tabular}

Table 2. Influence of modified atmospheric storage conditions on electrical conductivity $\left(\mathrm{dSm}^{-1}\right)$ of pigeonpea seeds during storage

\begin{tabular}{|c|c|c|c|c|c|c|}
\hline \multirow{2}{*}{\multicolumn{2}{|c|}{ Treatments }} & \multicolumn{5}{|c|}{ Months of storage (July-2012 to April 2013) } \\
\hline & & 2 & 4 & 6 & 8 & 10 \\
\hline $\mathrm{T}_{1}$ & : Control & 0.639 & 0.906 & 1.272 & 1.861 & 2.207 \\
\hline $\mathrm{T}_{2}$ & $: 70 \% \mathrm{~N}_{2}+20 \% \mathrm{O}_{2}+10 \% \mathrm{CO}_{2}$ & 0.632 & 0.877 & 1.266 & 1.796 & 2.153 \\
\hline $\mathrm{T}_{3}$ & $: 60 \% \mathrm{~N}_{2}+20 \% \mathrm{O}_{2}+20 \% \mathrm{CO}_{2}$ & 0.627 & 0.859 & 1.263 & 1.792 & 2.106 \\
\hline $\mathrm{T}_{4}$ & $: 40 \% \mathrm{~N}_{2}+20 \% \mathrm{O}_{2}+40 \% \mathrm{CO}_{2}$ & 0.623 & 0.853 & 1.257 & 1.777 & 2.098 \\
\hline $\mathrm{T}_{5}$ & $: 20 \% \mathrm{~N}_{2}+20 \% \mathrm{O}_{2}+60 \% \mathrm{CO}_{2}$ & 0.620 & 0.850 & 1.233 & 1.771 & 2.084 \\
\hline $\mathrm{T}_{6}$ & $: 80 \% \mathrm{~N}_{2}+10 \% \mathrm{O}_{2}+10 \% \mathrm{CO}_{2}$ & 0.619 & 0.811 & 1.221 & 1.767 & 2.077 \\
\hline $\mathrm{T}_{7}$ & $: 70 \% \mathrm{~N}_{2}+10 \% \mathrm{O}_{2}+20 \% \mathrm{CO}_{2}$ & 0.615 & 0.801 & 1.216 & 1.759 & 2.072 \\
\hline $\mathrm{T}_{8}$ & $: 50 \% \mathrm{~N}_{2}+10 \% \mathrm{O}_{2}+40 \% \mathrm{CO}_{2}$ & 0.613 & 0.791 & 1.192 & 1.741 & 2.070 \\
\hline $\mathrm{T}_{9}$ & $: \quad 30 \% \mathrm{~N}_{2}+10 \% \mathrm{O}_{2}+60 \% \mathrm{CO}_{2}$ & 0.610 & 0.789 & 1.187 & 1.739 & 2.062 \\
\hline $\mathrm{T}_{10}$ & $: 90 \% \mathrm{~N}_{2}+00 \% \mathrm{O}_{2}+10 \% \mathrm{CO}_{2}$ & 0.609 & 0.786 & 1.183 & 1.735 & 2.059 \\
\hline $\mathrm{T}_{11}$ & $: 80 \% \mathrm{~N}_{2}+00 \% \mathrm{O}_{2}+20 \% \mathrm{CO}_{2}$ & 0.607 & 0.785 & 1.182 & 1.733 & 2.057 \\
\hline $\mathrm{T}_{12}$ & $: 60 \% \mathrm{~N}_{2}+00 \% \mathrm{O}_{2}+40 \% \mathrm{CO}_{2}$ & 0.598 & 0.768 & 1.170 & 1.726 & 2.042 \\
\hline $\mathrm{T}_{13}$ & $: 40 \% \mathrm{~N}_{2}+00 \% \mathrm{O}_{2}+60 \% \mathrm{CO}_{2}$ & 0.597 & 0.765 & 1.165 & 1.721 & 2.029 \\
\hline $\mathrm{T}_{14}$ & : Vacuum & 0.602 & 0.772 & 1.180 & 1.728 & 2.045 \\
\hline & Mean & 0.615 & 0.815 & 1.213 & 1.760 & 2.083 \\
\hline & S.Em \pm & 0.011 & 0.013 & 0.016 & 0.018 & 0.024 \\
\hline & $\mathrm{CD}(5 \%)$ & NS & 0.037 & 0.049 & 0.053 & 0.072 \\
\hline
\end{tabular}

NS - Non significant

(Maristela and Roberval 2007).

Electrical conductivity of seed leachates (EC) increased with the advancement of storage period. The mean value of seed leachates (EC) increased from $0.513 \mathrm{dSm}^{-1}$ at the beginning to $2.083 \mathrm{dSm}^{-1}$ after ten months of storage. At the end of ten months of modified atmospheric storage period, lowest electrical conductivity of seed leachate was recorded in $\mathrm{T}_{13}\left(40 \% \mathrm{~N}_{2}\right.$ $\left.+0 \% \mathrm{O}_{2}+60 \% \mathrm{CO}_{2}\right)\left(2.029 \mathrm{dSm}^{-1}\right)$, which was preceded by $\mathrm{T}_{12}-\left(60 \% \mathrm{~N}_{2}+0 \% \mathrm{O}_{2}+40 \% \mathrm{CO}_{2}\right)(2.042 \mathrm{dSm}$ ${ }^{1}$ ) and this might be due to the better maintenance of membrane integrity while, the highest electrical conductivity was recorded in $\mathrm{T}_{1}$ control $\left(2.207 \mathrm{dSm}^{-1}\right)$. Increase in electrical conductivity with the storage period may be due to increased membrane permeability and decreased integrity of seed coat resulted in excess release of electrolytes which caused higher electrical conductivity (Table 2). Similar findings of Electrical conductivity of seed leachates (EC) were also observed by Shivappa (2011) in onion and Shrishail (2011) in groundnut.

Seed protein declined with the advancement of storage period. The mean protein content decreased from $20.90 \%$ at the initial stage to $19.03 \%$ after ten months of storage higher protein content of seed has been found to favour maintenance of vigour and viability during storage (Hewrton, 1994 and Ching and Schoolcraft, 1968). In present investigation, at the end of ten months of modified atmospheric storage period highest protein content was recorded in $\mathrm{T}_{13}\left(40 \% \mathrm{~N}_{2}+0 \%\right.$ $\left.\mathrm{O}_{2}+60 \% \mathrm{CO}_{2}\right) 19.33 \%$ followed by $\mathrm{T}_{12}-\left(60 \% \mathrm{~N}_{2}+0 \%\right.$ $\left.\mathrm{O}_{2}+40 \% \mathrm{CO}_{2}\right) 19.26 \%$ while the lowest protein content was recorded in $\mathrm{T}_{1}$ control $(18.13 \%)$. However, de- 
Table 3. Influence of modified atmospheric storage conditions on protein content (\%) of pigeonpea seeds during storage

\begin{tabular}{|c|c|c|c|c|c|c|}
\hline \multirow{2}{*}{\multicolumn{2}{|c|}{ Treatments }} & \multicolumn{5}{|c|}{ Months of storage (July-2012 to April 2013) } \\
\hline & & 2 & 4 & 6 & 8 & 10 \\
\hline $\mathrm{T}_{1}$ & : Control & 20.03 & 19.92 & 19.72 & 18.23 & 18.13 \\
\hline $\mathrm{T}_{2}$ & $: 70 \% \mathrm{~N}_{2}+20 \% \mathrm{O}_{2}+10 \% \mathrm{CO}_{2}$ & 20.06 & 19.98 & 19.79 & 19.00 & 18.93 \\
\hline $\mathrm{T}_{3}$ & $: 60 \% \mathrm{~N}_{2}+20 \% \mathrm{O}_{2}+20 \% \mathrm{CO}_{2}$ & 20.11 & 20.02 & 19.84 & 19.20 & 18.98 \\
\hline $\mathrm{T}_{4}$ & $: 40 \% \mathrm{~N}_{2}+20 \% \mathrm{O}_{2}+40 \% \mathrm{CO}_{2}$ & 20.13 & 20.04 & 19.86 & 19.33 & 19.00 \\
\hline $\mathrm{T}_{5}$ & $: 20 \% \mathrm{~N}_{2}+20 \% \mathrm{O}_{2}+60 \% \mathrm{CO}_{2}$ & 20.17 & 20.07 & 19.88 & 19.36 & 19.02 \\
\hline $\mathrm{T}_{6}$ & $: 80 \% \mathrm{~N}_{2}+10 \% \mathrm{O}_{2}+10 \% \mathrm{CO}_{2}$ & 20.22 & 20.08 & 19.93 & 19.44 & 19.07 \\
\hline $\mathrm{T}_{7}$ & $: 70 \% \mathrm{~N}_{2}+10 \% \mathrm{O}_{2}+20 \% \mathrm{CO}_{2}$ & 20.25 & 20.10 & 19.94 & 19.50 & 19.08 \\
\hline $\mathrm{T}_{8}$ & $: 50 \% \mathrm{~N}_{2}+10 \% \mathrm{O}_{2}+40 \% \mathrm{CO}_{2}$ & 20.28 & 20.12 & 19.96 & 19.52 & 19.10 \\
\hline $\mathrm{T}_{9}$ & $: 30 \% \mathrm{~N}_{2}+10 \% \mathrm{O}_{2}+60 \% \mathrm{CO}_{2}$ & 20.29 & 20.13 & 19.98 & 19.54 & 19.12 \\
\hline $\mathrm{T}_{10}$ & $: 90 \% \mathrm{~N}_{2}+00 \% \mathrm{O}_{2}+10 \% \mathrm{CO}_{2}$ & 20.30 & 20.14 & 20.00 & 19.56 & 19.14 \\
\hline $\mathrm{T}_{11}$ & $: 80 \% \mathrm{~N}_{2}+00 \% \mathrm{O}_{2}+20 \% \mathrm{CO}_{2}$ & 20.32 & 20.16 & 20.01 & 19.58 & 19.16 \\
\hline $\mathrm{T}_{12}$ & $: 60 \% \mathrm{~N}_{2}+00 \% \mathrm{O}_{2}+40 \% \mathrm{CO}_{2}$ & 20.43 & 20.22 & 20.05 & 19.63 & 19.26 \\
\hline $\mathrm{T}_{13}$ & $: 40 \% \mathrm{~N}_{2}+00 \% \mathrm{O}_{2}+60 \% \mathrm{CO}_{2}$ & 20.59 & 20.35 & 20.08 & 19.65 & 19.33 \\
\hline $\mathrm{T}_{14}$ & : Vacuum & 20.34 & 20.20 & 19.99 & 19.60 & 19.19 \\
\hline & Mean & 20.25 & 20.10 & 19.93 & 19.36 & 19.03 \\
\hline & S.Em \pm & 0.406 & 0.050 & 0.037 & 0.246 & 0.121 \\
\hline & $\mathrm{CD}(5 \%)$ & NS & 0.147 & 0.108 & 0.714 & 0.352 \\
\hline
\end{tabular}

NS - Non significant

crease in the protein content was observed in all the treatments as the storage period advanced (Table 3 ). Similar findings of seed protein were also observed by Shehata et al. (2009) The cowpea seeds treated with gases mixture containing $80 \% \mathrm{CO}_{2}+4 \% \mathrm{O}_{2}+16 \%$ $\mathrm{N}_{2}$ showed highest total crude protein , while untreated seeds showed the lowest total crude protein.

\section{Conclusion}

It is evident from present study that the seeds stored in polyethylene bags without gases shows higher electrical conductivity of seed leachates (EC), lower dehydrogenase activity and protein content where, as seeds stored in gaseous combination of higher concentration of carbon dioxide and zero percentage of oxygen shows lower EC, higher dehydrogenase activity and protein content. The correlation of biochemical parameters correlated with the vigour and viability of pigeonpea seeds showed that the electrical conductivity of seed leachates (EC) increases, vigour and viability of pigeonpea seeds decreases and high dehydrogenase activity and seed protein content was found to favour maintenance of vigour and viability during storage. Pigeon pea seeds packed with gaseous combination of higher concentration of carbon dioxide $(60 \%)$ and zero percentage of oxygen enhances the seed longevity with higher seed quality parameters.

\section{REFERENCES}

Anonymous, (2012). Ann. Prog. Rept., All India Coordinated Research Project on Pigeonpea. IIPR, Kanpur, pp. 240.

Bailey, S. W. and Banks, H. J. (1980). Controlled Atmosphere Storage of Grains. Elsevier Scientific Publishing Co, Amsterdam, Germany, pp. 101-118.Ching, T. M. and Schoolcraft, I. (1968). Physiological and chemical differences in aged seeds. CropSci., 8: 407-411.

Halder, S. and Gupta, K. (1982). Mechanism of sunflower seed deterioration under low and high relative humidity,
Seed Sci. \& Technol., 10: 267-270.

Hewrton, L. J. (1994). Seed size studies on some vegetable species. M.Sc. (Agri) Thesis, Tamil Nadu Agric. Univ., Coimbatore.

Jayas, D. S. and Jeyamkondan, S. (2002). Modified atmosphere storage of grains meats fruits and vegetables, Biosystems Engineering., 82: 235-251.

Julio, M. F. (2015) Seed vigor testing: an overview of the past, present and future perspective.

Sci. Agric., 72:363-374

Kharlukhi, L. (1983). Physiological and biochemical changes in seeds during storage under controlled condition. Ph.D.Thesis, IARI, New Delhi.

Kittock, P. A. and Law, A. G. (1968). Relationship of seedling vigour to respion and tetrazolium chloride reduction of germinating wheat seeds. Agron. J., 60: 286-288.

Lowry, O. H., Rosebrough, N. J., Farr, A. L. and Randall, R. J. (1951). Protein measurement with the Folin phenol reagent. J. Biol. Chem., 193: 265-275.

Maristela, P. and Roberval, D. V.(2007) Electrical conductivity and deterioration of soybean seeds exposed to different storage conditions, Revista Brasileira de Sementes., 2:97-105

Rudrapal, A. B. and Basu, R. N. (1970). Lipid peroxidation and membrane damage in deterioration of wheat and mustard seed. Indian J. Expt. Biol., 20: 465-470.

Saxena, V. P., Singh, G., Pakuraiah, T. and Pandey, N. (1987). Seed deterioration studies in some vegetable seeds. Acta. Hortic., 215: 39-44.

Shehata S. A., Hashem, M. Y. and Abd El-Gawad K. F. (2009). Effect of controlled atmosphere on quality of dry cowpea seeds.4th Conference on Recent Technology in Agriculture, Faculty of Agriculture, Cairo University, Giza, Egypt.

Shrishail, T. (2011), Studies on the effect of modified atmospheric storage condition on storability of groundnut seed kernels. M.Sc. (Agri) Thesis, UAS, Raichur.

Shivappa, R. (2011). Studies on the effect of modified atmospheric storage condition on storability of onion seeds. M.Sc. (Agri) Thesis, UAS, Raichur. 